\title{
Cellulose Nano Whiskers as a Reinforcing Filler in Polyurethanes
}

\author{
Yang Li and Arthur J. Ragauskas \\ Institute of Paper Science and Technology, \\ School of Chemistry and Biochemistry, \\ Georgia Institute of Technology, Atlanta, \\ USA
}

\section{Introduction}

Bio-based polymers and biocomposites are a relatively new and growing market in light of recent societal concerns including dwindling petroluem reserves, environmental and endof-live disposal issues (Mohanty et al., 2005; Vijay, 2009). Polymers derived from plants, especially those from non-food resources, are gaining the attention of governments, industries and institutes, primarily due to their environmental compatibility, superior physical properties and low stable market prices which are becoming competitive with petroleum-derived polymers. The three major chemical components of biomass, cellulose, hemicellulose and lignin are utilized in diverse fields, such as biofuels, particularly bioethanol and green diesel, biomaterials, including conventional composites and novel nanocomposites, and other value-added chemicals. Among them, cellulose is the most abundant biopolymer in the world with a total annual biomass production of about $1.5 \times$ $10^{12}$ tons (Klemm et al., 2005). It has led to a large body of research due to its renewable nature, wide availability, non-food agricultural based economy, low density, high specific strength and modulus, high aspect ratio and reactive surface (Samir et al., 2005). Cellulose is a polydispersed linear polymer of $\beta-(1,4)$-D-glucose. A cellulose fiber is composed of bundles of microfibrils where the cellulose chains are stabilized laterally by inter and intramolecular hydrogen bonding. Microfibrils are comprised of elementary fibrils where monocrystalline domains are linked by amorphous domains. Generally, monocrystallite cellulose has been reported with length ranges from 100 to $300 \mathrm{~nm}$ and diameter between 5 and $20 \mathrm{~nm}$. In other words, cellulose monocrystallite has a high aspect ratio of 20-60 (Helbert et al., 1996; Eichhorn et al., 2001; Mathew \& Dufresne, 2002; Morin \& Dufresne, 2002; Samir et al., 2004). Table 1 summarizes the degree of crystallinity and the lateral dimension of elementary fibrils from several cellulose samples measured by X-ray diffraction (XRD). Tensile strength and modulus of native cellulose crystallites are approximately $10000 \mathrm{MPa}$ and $150 \mathrm{MPa}$, respectively (Kamel, 2007). Under certain process conditions, transverse cleavage of the cellulose happens primarily in the amorphous zone of the fiber and releases needle-like monocrystals referred to as cellulose nano whiskers. Whisker dimensions depend on both the origin of the cellulose and reaction conditions employed. In general, wood and cotton cellulose nano whiskers have a smaller length and cross section compared to those derived from tunicate, bacterial and algae (Hanley et al., 1992; Terech et al., 1999; 
Grunert \& Winter, 2002; Beck-Candanedo et al., 2005), which is in agreement with the degree of crystallinity and the lateral dimension of elementary fibrils. Cellulose nano whiskers exhibit not only a high elastic modulus of 143 GPa (Sturcova et al., 2005), but also show significant changes in electrical, optical, and magnetic properties in comparison to native cellulosic fibers (Samir et al., 2005). There has been a growing interest in cellulose nano whisker reinforced composites in the last decade, and improvements in mechanical and thermal properties are readily achieved. (Dufresne et al., 1999; Mathew \& Dufresne, 2002; Bondeson \& Oksman, 2007).

\begin{tabular}{lll}
\hline Sample & $\mathrm{C}, \%$ & $\mathrm{D}, \mathrm{nm}$ \\
\hline Natural softwood/hardwood cellulose & $60-62$ & $3-4$ \\
Isolated sulfite cellulose & $62-63$ & $5-6$ \\
Isolated Kraft cellulose & $64-65$ & $6-7$ \\
Natural cotton cellulose & $68-69$ & $5-6$ \\
Isolated cotton cellulose & $70-72$ & $7-8$ \\
Natural flax or ramie cellulose & $65-66$ & $4-5$ \\
Isolated flax or ramie cellulose & $67-68$ & $6-7$ \\
Bacterial cellulose & $75-80$ & $7-8$ \\
Algae cellulose & $75-80$ & $10-15$ \\
\hline
\end{tabular}

Table 1. Degree of crystallinity (C) and lateral dimension (D) of elementary fibrils from several cellulose samples (Ioelovich, 1993; Ioelovich \& Larina, 1999; Grunert \& Winter, 2002; Ioelovich, 2009; Ioelovich \& Leykin, 2009).

Polyurethane (PU) is any polymer consisting of a chain of organic units joined by urethane linkages (-NHCOO-). It is formed through a step-wise polymerization by reacting a monomer containing at least two isocyanate groups with another monomer containing at least two hydroxyl groups in presence of a catalyst (Pascault et al., 2002). PU has rapidly grown to be one of the most diverse and widely-used materials with a continuously increasing global market since its first lab synthesis in 1937 by Otto Bayer and co-workers (Vermette et al., 2001). Compared to conventional materials, e.g., wood and metals, polyurethane has its own unique merits, such as low density, thermal conductivity and moisture permeability, a high strength to weight ratio, and dimensional stability (Lim et al., 2008). In addition, the formulation and reaction conditions can be readily adjusted to synthesize PUs with desired properties for specific applications. Nowadays, PU is primarily used for construction, packaging, insulation, bedding, upholstery, footwear, and vehicle parts, in forms of rigid, semi-rigid and flexible foams with a wide range of densities, as well as elastomers. Despite the significant benefits of PU, it still exehibits some drawbacks including poor degradability and toxicity due to the use of isocyanates which have evoked researchers to find more environmental friendly starting materials. Moreover, the mechanical and thermal properties of PU are not optimial in comparison to other synthetic polymers like polystyrene. These drawbacks have continued to spur research into PU composites, especially nanocomposites, considering the superior properties that can be acquired by the introduction of nano particles into a PU product. In recent years, cellulose nano whiskers have been used as a reinforcing filler in PU synthesis, and improvements of both thermal and mechanical properties have been reported (Marcovich et al., 2006; Cao et al., 2007; Auad et al., 2008; Cao et al., 2009; Auad et al., 2010; Li et al., 2010a; Wang et al., 2010). Since different types of PU have been investigated through various preparation methods and characterization techniques, a summary and comparation with regard to the PU nanocomposite synthesis and a detailed discussion of the properties, 
mechanisms and other associated issues will facilitate future applications of cellulose nano whiskers in PU and other related polymers.

\section{Cellulose nano whisker}

\subsection{Preparation of cellulose nano whiskers}

During the past twenty years, research on cellulose nano whiskers has been extensively developed. Softwood (SW) kraft pulp (Revol et al., 1994; Araki et al., 1998; Araki et al., 1999; $\mathrm{Pu}$ et al., 2007), SW sulfite pulp (Beck-Candanedo et al., 2005), hardwood (HW) ECF (elemental chlorine free) pulp (Beck-Candanedo et al., 2005), recycle pulp (Filson et al., 2009), cotton fiber (Revol et al., 1994; Dong et al., 1996; Dong et al., 1998; Araki et al., 2000; Hasani et al., 2008; Cao et al., 2009; Pei et al., 2010; Tang \& Weder, 2010; Wang et al., 2010), sisal fiber (de Rodriguez et al., 2006; Tang \& Weder, 2010), flax fiber (Cao et al., 2007), ramie fiber (Habibi et al., 2007; Habibi \& Dufresne, 2008; Zoppe et al., 2009), wheat straw (Helbert et al., 1996), bamboo residue (Liu et al., 2010), bacterial microfibrils (Grunert \& Winter, 2002), grass fiber (Pandey et al., 2009), tunicate cellulose (Favier et al., 1995; Angles \& Dufresne, 2000; Sturcova et al., 2005; Ljungberg et al., 2006; Habibi et al., 2007; Siqueira et al., 2010; Tang \& Weder, 2010), microcrystalline cellulose (MCC) (Samir et al., 2004; Samir et al., 2004; Bondeson et al., 2006; Oksman et al., 2006; Bondeson \& Oksman, 2007; Bai et al., 2009; Auad et al., 2010; Liu et al., 2010) have all been utilized as cellulose sources for whiskers.

The most common preparation method employed is acid hydrolysis, including acid sulfuric and hydrochloric acid. Other methods, such as enzymatic hydrolysis and mechanical disintegration have also been used. Cellulose fibers are usually disintegrated by a Wiley mill to pass through a 20 mesh screen before acid hydrolysis. Sulfuric acid concentrations of $60-$ $70 \%(\mathrm{w} / \mathrm{w})$, more often $64 \%$, is preferred (Revol et al., 1994). Acid treatment can range from $10 \mathrm{~min}$ at $70{ }^{\circ} \mathrm{C}$ to 3 hours at $45{ }^{\circ} \mathrm{C}$ at select acid to cellulose ratios, and the reaction is typically quenched by diluting with a 10 fold addition of deionized (DI) water. The sediment, cellulose nano whiskers, is then collected and neutralized by repeated centrifugation and prolonged dialysis against deionized water until the $\mathrm{pH}$ of the whiskers suspension does not change. For specific investigations and/or application purposes, all ions except $\mathrm{H}^{+}$associated with sulfate groups on the surface of $\mathrm{H}_{2} \mathrm{SO}_{4}$ generated whiskers need to be removed. This can be achieved by treating the whisker suspension with a mixedbed ion exchange resin and filtering through a $0.45 \mu \mathrm{m}$ membrane (Dong et al., 1996). Afterward, ultrasonic treatment is necessary to seperate nano whiskers. A plastic reaction flask is preferred to avoid the release of ions from the glass container and the solution needs to be chilled to avoid overheating which could cause desulfation (Dong et al., 1998). Recently, cellulose nano whiskers were also prepared by sulfuric acid hydrolysis of cotton fiber (Hasani et al., 2008), MCC (Bondeson et al., 2006; Bai et al., 2009), and sisal fiber (Siqueira et al., 2010) which followed the same general procedure described above. Whiskers with a narrow size distribution were obtained through differential centrifugation techniques (Bai et al., 2009). A comprehensive compilation of preparation conditions employing sulfuric acid and the average dimensions of cellulose nano whiskers derived from different sources is shown in Table 2.

During sulfuric acid hydrolysis, esterification of cellulose hydroxyl groups to sulfate groups occurs (Figure 1) which can introduce negative charges to the nano whiskers and this provides improved suspension stability. The sulfate content of cellulose nano whiskers can be determined by a conductimetric method described by Araki et al. (1998). A whiskers suspension $(\sim 0.01 \mathrm{~g} / \mathrm{mL}, 45 \mathrm{~mL})$ is mixed with a $\mathrm{NaCl}$ solution $(0.01 \mathrm{M}, 5 \mathrm{~mL})$ before measurement. For samples with poor or no sulfonation, $3 \mathrm{~mL}$ of water is replaced by 0.01 


\begin{tabular}{|c|c|c|c|c|c|}
\hline $\begin{array}{l}\text { Cellulose } \\
\text { source }\end{array}$ & $\begin{array}{l}\mathrm{H}_{2} \mathrm{SO}_{4} \text { conc., } \\
\%(\mathrm{w} / \mathrm{w})\end{array}$ & $\begin{array}{l}\text { Time, } \\
\text { min }\end{array}$ & $\mathrm{T},{ }^{\circ} \mathrm{C}$ & $\begin{array}{l}\text { Acid/cellulose, } \\
\mathrm{mL} / \mathrm{g}\end{array}$ & $\begin{array}{l}\text { Dimension, } \\
\mathrm{nm}^{2}\end{array}$ \\
\hline \multirow[t]{5}{*}{ SW pulp } & 64 & 10 & 70 & 8.75 & $\sim 200 \times 5$ \\
\hline & 60 & 50 & $<70^{\circ} \mathrm{C}$ & 8.75 & $\sim 200 \times 5$ \\
\hline & 65 & 10 & 70 & 10 & $185 \pm 75 \times \sim 3.5$ \\
\hline & 65 & 60 & 45 & 8.75 & $185 \pm 75 \times \sim 3.5$ \\
\hline & 64 & 45 & 45 & 17.5 & $100-250 \times 5-15$ \\
\hline \multirow[t]{4}{*}{ HW pulp } & 64 & 25 & 45 & 8.75 & $147 \pm 7 \times 3-5$ \\
\hline & 64 & 25 & 45 & 8.75 & $141 \pm 6 \times 5.0 \pm 0.3$ \\
\hline & 64 & 45 & 45 & 8.75 & $120 \pm 5 \times 4.9 \pm 0.3$ \\
\hline & 64 & 45 & 45 & 17.5 & $105 \pm 4 \times 4.5 \pm 0.3$ \\
\hline \multirow[t]{5}{*}{ Cotton } & 64 & 120 & 45 & 8.75 & $\sim 200 \times 5$ \\
\hline & 64 & 60 & 45 & 8.75 & $115 \pm 10 \times \sim 7$ \\
\hline & 64 & 45 & 45 & 17.5 & $176 \pm 21 \times 13 \pm 3$ \\
\hline & 64 & 120 & 60 & 8.33 & $70-150 \times 10-20$ \\
\hline & 65 & 60 & 45 & 8.75 & $100-150 \times 5-10$ \\
\hline Sisal & 65 & 15 & 60 & 16.2 & $\sim 250 \times 4$ \\
\hline Flax & 64 & 240 & 45 & 8.33 & $327 \pm 108 \times 21 \pm 7$ \\
\hline Wheat straw & 65 & 60 & 25 & 34.3 & $150-300 \times \sim 5$ \\
\hline \multirow[t]{4}{*}{$\mathrm{MCC}$} & 63.5 & 130.3 & 44 & 10 & $200-400 \times<10$ \\
\hline & 64 & 300 & 45 & 8.75 & $41-320 x<100$ \\
\hline & 64 & 180 & 45 & 17.5 & $60-120 \times 8-10$ \\
\hline & 64 & - & 45 & 8.75 & $100-225 \times 10-15$ \\
\hline
\end{tabular}

Table 2. Dimensions of cellulose nano whsikers prepared under different sulfuric acid hydrolysis conditions (Revol et al., 1994; Favier et al., 1995; Dong et al., 1996; Helbert et al., 1996; Araki et al., 1998; Dong et al., 1998; Araki et al., 1999; Beck-Candanedo et al., 2005;

Bondeson et al., 2006; de Rodriguez et al., 2006; Cao et al., 2007; Hasani et al., 2008; Bai et al., 2009; Cao et al., 2009; Auad et al., 2010; Liu et al., 2010).

$\mathrm{M} \mathrm{HCl}$ in order to obtain a preferred value (Bondeson et al., 2006). An alkaline solution (0.1 $\mathrm{N} \mathrm{NaOH}$ ) is then added to the suspension at a rate of $0.5 \mathrm{~mL}$ per 5 min with continuous stirring. The change in conductivity is recorded by a electric conductometer. Theoretically, the two branches of the titration curve should intercept the volume axis at the same value which is the equivalence-point volume. However, in some cases, the abscissa intercepts due to the dissociation of cellulosic carboxylic acid groups after the stronger sulfate groups have been neutralized (Roman \& Winter, 2004). The actual equivalence-point volume is then determined as the average of the two volumes. The degree of sulfonation relies highly on the acid to cellulose ratio and the reaction time as shown in Table 3.

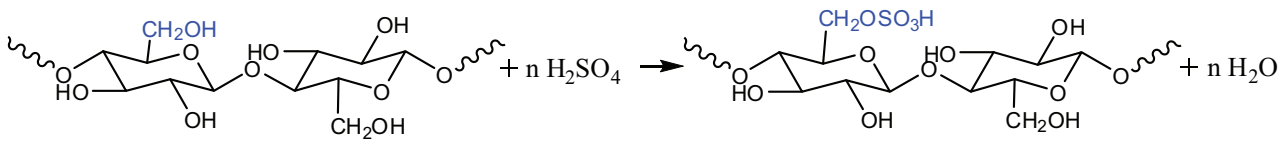

Fig. 1. Esterification of cellulose hydroxyl groups during sufuric acid hydrolysis. 


\begin{tabular}{llll}
\hline Pulp:acid & Reaction time, min & Sulfur content ${ }^{\mathrm{a}}, \%$ & DS $^{\mathrm{b}}$ \\
\hline $1: 4$ & 16 & 49.540 & 1.670 \\
& 17 & 59.290 & 2.000 \\
$1: 6$ & 45 & 56.670 & 1.910 \\
& 15 & 59.110 & 1.995 \\
& 19 & 59.840 & 2.020 \\
$1: 8$ & 18 & 46.260 & 1.560 \\
& 15 & 62.260 & 2.102 \\
& 20 & 59.440 & 2.013 \\
$1: 10$ & 45 & 53.290 & 1.793 \\
& 15 & 60.700 & 2.049 \\
& 23 & 63.100 & 2.129 \\
\hline
\end{tabular}

a Sulfur content is the percentage of sulfur groups based on the total number of hydroxyl and sulfur groups; b degree of substitution (DS) is calculated as the average number of hydroxyl groups in the anhydroglucose that are substituted in the particular product.

Table 3. Effect of sulfuric acid $(72 \%, \mathrm{w} / \mathrm{w})$ hydrolysis condition on the degree of sulfonation of linen pulp (Selim et al., 2004).

The effects of hydrolysis temperature, time, and ultrasonic treatment duration on the properties of cellulose nano whiskers were investigated (Dong et al., 1998) according to an experimental setup illustrated in Table 4 . It was shown that with $64 \%(\mathrm{w} / \mathrm{w})$ sulfuric acid and an acid to cellulose ratio of $8.75 \mathrm{~mL} / \mathrm{g}, 18$ hours was required to produce nano whiskers at 26 ${ }^{\circ} \mathrm{C}$. At $65{ }^{\circ} \mathrm{C}$, hydrolysis could not be controlled easily, a yellow color appeared at the first 10 min, and the sample became black after 1 hour. Side reactions, e.g., dehydration, were presumed to occur under this condition. A temperature of $45^{\circ} \mathrm{C}$ was proposed to be optimal and could lead to an efficient hydrolysis yielding an ivory-white colored suspension with a reported yield of $44 \%$ after 1 hour. It was also found that the total sulfur content and surface charge of nano whiskers gradually increased when increasing the hydrolysis reaction time from 10 to $240 \mathrm{~min}$ at $45^{\circ} \mathrm{C}$. The whiskers size decreased in the early stage of the hydrolysis and a relatively stable dimension was achieved after 1 hour as summarized in Table 5 . The appearance of the whiskers suspension could be white with some starting pulp particles (low yield), ivory white viscous suspension (optimal), yellowish or even black viscous suspension (over hydrolyzed) (Dong et al., 1998). The particle size decreased within the first $5 \mathrm{~min}$ of ultrasonic treatment but no further change was observed upon extended treatment, while the surface charge of cellulose nano whiskers remained constant (Dong et al., 1998). The effect of ultrasonic treatment on whiskers size and surface charge is shown in Table 6. Nevertheless, a 15 min of ultrasonic treatment was reported to produce well separated Korean grass cellulose nano whiskers of $10 \mathrm{~nm}$ thickness and several nano-sized lengths, while $5 \mathrm{~min}$ of ultrasonic treatment time only resulted in nano-sized (40-50 nm thickness) agglomerates (Pandey et al., 2009). Subsequent studies by Beck-Candanedo et al. (2005) also investigated the effect of hydrolysis time on the properties and behaviors of cellulose nano whiskers. A black spruce sulfite pulp and bleached eucalyptus kraft pulp were treated with $64 \%(\mathrm{w} / \mathrm{w})$ sulfuric acid at $45^{\circ} \mathrm{C}$. It was shown that longer hydrolysis time produced shorter, less polydispersed whiskers while increased acid to cellulose ratios reduced whiskers dimensions.

To optimize the isolation of cellulose nano whiskers, Bondeson et al. (2006) performed a series of acid hydrolysis experiments with MCC prepared from Norway spruce sulfite pulp using a response surface methodology. Factors included hydrolysis time, temperature, acid 
concentration, acid to cellulose ratio, and ultrasonic treatment duration. The dimension and yield of whiskers served as the experimental response factors. A summary of this study in terms of experimental conditions and results is shown in Table 7. It was found that MCC required a longer time to be hydrolyzed with to nano whiskers. Briefly, the optimal condition was determined to be sulfuric acid concentration of $63.5 \%(\mathrm{w} / \mathrm{w})$, acid to cellulose ratio of $10 \mathrm{~mL} / \mathrm{g}$, and $130 \mathrm{~min}$ hydrolysis at $44{ }^{\circ} \mathrm{C}$ followed by approximately $30 \mathrm{~min}$ ultrasonic treatment, which produced whiskers of 200 to $400 \mathrm{~nm}$ in length and less than 10 $\mathrm{nm}$ in width and a yield of $30 \%$ of the initial weight. In the above mentioned studies, different ultrasonic treatment times were reported to obtain well separated whiskers. This was probably due to the non-uniform concentration and volume of whiskers suspension as well as various ultrasonic equipment and output.

\begin{tabular}{lllll}
\hline Sample & $\mathrm{T},{ }^{\circ} \mathrm{C}$. & Time, $\mathrm{h}$ & Appearance of the suspension & Yield, $\%(\mathrm{w} / \mathrm{w})$ \\
\hline 1 & 25 & 1 & White, with pulp particles & 89.8 \\
2 & 25 & 18 & Ivory white, viscous & 34.4 \\
3 & 45 & 1 & Ivory white, viscous & 43.5 \\
4 & 65 & 0.25 & Yellow, very viscous & 48.1 \\
5 & 65 & 1 & Black & $\mathrm{N} / \mathrm{A}$ \\
\hline
\end{tabular}

Table 4. Effect of hydrolysis condition on the appearance of cellulose nano whiskers suspension (Dong et al., 1998).

\begin{tabular}{llll}
\hline Sample & Hydrolysis time, $\min$ & Sulfur content $\mathrm{a}^{\mathrm{a}}$ & Whisker length, $\mathrm{nm}$ \\
\hline 1 & 10 & 0.53 & 390 \\
2 & 20 & 0.50 & 332 \\
3 & 30 & 0.58 & 276 \\
4 & 45 & 0.62 & 226 \\
5 & 60 & 0.69 & 197 \\
6 & 120 & 0.74 & 179 \\
7 & 240 & 0.75 & 177 \\
\hline
\end{tabular}

a Sulfur content is the percentage of sulfur groups based on the total number of hydroxyl and sulfur groups.

Table 5. Effect of sulfuric acid hydrolysis time at $45^{\circ} \mathrm{C}$ on the sulfur content and length of cellulose nano whiskers (Dong et al., 1998).

\begin{tabular}{lll}
\hline Treatment time, $\min$ & Whisker length, $\mathrm{nm}$ & Sulfur content $^{\mathrm{a}}$ \\
\hline 1 & 214 & 0.484 \\
2 & 205 & 0.487 \\
5 & 182 & 0.482 \\
10 & 183 & 0.489 \\
20 & 176 & 0.507 \\
40 & 182 & 0.503 \\
\hline
\end{tabular}

a Sulfur content is the percentage of sulfur groups based on the total number of hydroxyl and sulfur groups.

Table 6. Effect of ultrasonic treatment on the length and surface charge of cellulose nano whiskers (Dong et al, 1998). 


\begin{tabular}{llllllll}
\hline Sample & $\begin{array}{l}\mathrm{MCC} \\
\text { conc., } \\
\mathrm{g} / 100 \mathrm{~mL}\end{array}$ & $\begin{array}{l}\mathrm{H}_{2} \mathrm{SO}_{4} \\
\text { conc., } \\
\%(\mathrm{w} / \mathrm{w})\end{array}$ & $\begin{array}{l}\text { Hydrolysis } \\
\text { time, } \\
\text { min }\end{array}$ & $\begin{array}{l}\mathrm{T}, \\
{ }^{\circ} \mathrm{C}\end{array}$ & $\begin{array}{l}\text { Utrasonic } \\
\text { teatment } \\
\text { time, min }\end{array}$ & $\begin{array}{l}\text { Whiskers } \\
\text { length, } \\
\mu \mathrm{m}\end{array}$ & $\begin{array}{l}\text { Yield, } \\
\%\end{array}$ \\
\hline 1 & 5 & 44.1 & 10 & 40 & 30 & 19.34 & 93 \\
2 & 5 & 44.1 & 10 & 80 & 10 & 9.12 & 88 \\
3 & 5 & 64.8 & 10 & 40 & 10 & 38.68 & 91 \\
4 & 5 & 64.8 & 10 & 80 & 30 & 10.82 & 47 \\
5 & 5 & 44.1 & 120 & 40 & 10 & 14.30 & 94 \\
6 & 5 & 44.1 & 120 & 80 & 30 & 7.01 & 92 \\
7 & 5 & 64.8 & 120 & 40 & 30 & 0.11 & 34 \\
8 & 5 & 64.8 & 120 & 80 & 10 & - & 0 \\
9 & 15 & 44.1 & 10 & 40 & 10 & 22.36 & 95 \\
10 & 15 & 44.1 & 10 & 80 & 30 & 8.53 & 90 \\
11 & 15 & 64.8 & 10 & 40 & 30 & 14.91 & 73 \\
12 & 15 & 64.8 & 10 & 80 & 10 & 12.69 & 23 \\
13 & 15 & 44.1 & 120 & 40 & 30 & 13.80 & 95 \\
14 & 15 & 44.1 & 120 & 80 & 10 & 6.88 & 86 \\
15 & 15 & 64.8 & 120 & 40 & 10 & 0.18 & 18 \\
16 & 15 & 64.8 & 120 & 80 & 30 & - & 0 \\
17 & 10 & 55.1 & 65 & 60 & 20 & 7.96 & 82 \\
18 & 10 & 55.1 & 65 & 60 & 20 & 8.15 & 78 \\
19 & 10 & 55.1 & 65 & 60 & 20 & 7.84 & 78 \\
\hline
\end{tabular}

Table 7. Optimization of cellulose nano whiskers isolation

With regards to the hydrochloric acid hydrolysis, cellulose fibers are usually treated with 4 $\mathrm{N} \mathrm{HCl}$ at $80{ }^{\circ} \mathrm{C}$ for approximately 4 hours at an acid to cellulose ratio of $30-35 \mathrm{~mL} / \mathrm{g}$. Centrifugation, dialysis, and ultrasonic treatment are followed afterwards with the same conditions used for sulfuric acid hydrolysis. The $\mathrm{pH}$ value of $\mathrm{HCl}$-whiskers suspension is $\sim 6$, while that of $\mathrm{H}_{2} \mathrm{SO}_{4}$-whiskers level off at 2-3 which is attributed to the sulfate groups (Araki et al., 1998). The overall mass yield of $\mathrm{HCl}$-whiskers $(10-20 \%)$ is lower than $\mathrm{H}_{2} \mathrm{SO}_{4}$ whiskers (70-75\%) (Araki et al., 2000). HCl-whiskers of SW kraft pulp were reported to be approximately $180 \mathrm{~nm}$ in length and $3.5 \mathrm{~nm}$ in width, while cotton yielded $\mathrm{HCl}$-whiskers were around $100 \mathrm{~nm}$ in length and 5-10 nm in width (Araki et al., 1998; Araki et al., 1999; Araki et al., 2000).

Compared to the hydrochloric acid procedure, sulfuric acid hydrolysis needs lower temperature, acid to cellulose ratio, and less time to produce whiskers of similar dimensions as illustrated in Table 8. Moreover, it was proposed that the static electronic repulsion between negatively charged sulfates resulted in a more stable suspension instead of easily aggregated whiskers and it was the same reason given for the time independence of suspension viscosity (Kamel, 2007). A HCl-whiskers suspension was found to be thixotropic at concentrations $>0.5 \%(\mathrm{w} / \mathrm{v})$ and anti-thixotropic $<0.3 \%(\mathrm{w} / \mathrm{v})$ (Araki et al., 1998). In order to investigate the influence of sulfate groups on viscosity properties of whiskers suspension, Araki et al. (1999, 2000) introduced sulfate groups to HCl-whiskers by postsulfonation. Briefly, $\mathrm{HCl}$-whiskers precipitated after centrifugation were mixed with $65 \%(\mathrm{w} / \mathrm{w})$ sulfuric acid to yield a final acid concentration of $55 \%(\mathrm{w} / \mathrm{w})$ and reacted in a waterbath at $40{ }^{\circ} \mathrm{C}$ or $60{ }^{\circ} \mathrm{C}$ for 2 hours, which was quenched by adding large amounts of cold water. The number 
of sulfate groups was controlled by changing experimental factors, such as time and temperature. For example, treatment of an $\mathrm{HCl}$-whiskers suspension with equal weight amount of concentrated sulfuric acid at $60{ }^{\circ} \mathrm{C}$ overnight resulted in a sulfate content of 38 $\mathrm{mmol} / \mathrm{kg}$, which was much lower than that of $\mathrm{H}_{2} \mathrm{SO}_{4}$-whiskers $(140 \mathrm{mmol} / \mathrm{kg}$ ) (Araki et al., 2000). An increase of sulfate groups was observed when the postsulfonation reaction was conducted at $40{ }^{\circ} \mathrm{C}$ for 2 hours (Araki et al., 1999). It was shown that whiskers with a lower content of sulfate groups showed a slight viscosity increase with time at high solid contents, though it was not as significant as $\mathrm{HCl}$-whiskers. However, HCI-whiskers treated at $40{ }^{\circ} \mathrm{C}$ showed nearly the same level of viscosity properties as a $\mathrm{H}_{2} \mathrm{SO}_{4}$-whiskers suspension. It was also found that viscosity was strongly affected within a surface charge content of 50-60 $\mathrm{mmol} / \mathrm{kg}$. In summary, although the microscopic size and shape of whiskers could be the same irrespective of preparation method, the introduction of the surface charge drastically reduced the viscosity of whiskers suspension and removed its time dependencey.

\begin{tabular}{lllll}
\hline Acid & $\begin{array}{l}\text { Acid/cellulose, } \\
\mathrm{mL} / \mathrm{g}\end{array}$ & $\begin{array}{l}\text { Time, } \\
\min \end{array}$ & $\begin{array}{l}\mathrm{T}, \\
{ }^{\circ} \mathrm{C}\end{array}$ & $\begin{array}{l}\text { Whiskers dimension, } \\
\mathrm{nm}^{2}\end{array}$ \\
\hline $\mathrm{H}_{2} \mathrm{SO}_{4}, 65 \%(\mathrm{w} / \mathrm{w})$ & 8.75 & 60 & 45 & $185 \pm 75 \times \sim 3.5$ \\
$\mathrm{HCl}, 4 \mathrm{~N}$ & 30 & 225 & 80 & $180 \pm 80 \times 3.5 \pm 0.5$ \\
\hline
\end{tabular}

Table 8. Comparion between $\mathrm{H}_{2} \mathrm{SO}_{4}$ - and $\mathrm{HCl}$-whiskers (Araki et al., 1999).

Tunicate, a sea animal, has a mantle (tunic) composed of well organized and highly crystalline cellulosic fibrils, and is also widely used to prepared cellulose nano whiskers as an alternative to wood-based materials. The whiskers preparation procedure is more complicated and is summarized in Favier et al. study (1995). In brief, small fragments of tunic were first deproteinized by three succesive bleaching treatments. Each process involved a 1 hour reaction of $5 \mathrm{~g}$ tunic at $70-80{ }^{\circ} \mathrm{C}$ with $160 \mathrm{~mL}$ of water containing $1.5 \mathrm{~g}$ of sodium chlorite and 10 drops of glacial acetic acid as described elsewhere (Wise et al., 1946). The bleached tunicin was disintegrated in water, first by using a blender at a concentration of $5 \mathrm{wt} \%$ and then via 15 passes through a laboratory homogenizer operated at 400 bar at a lower concentration of 1 $\mathrm{wt} \%$. The aqueous tunicin suspension was then mixed with sulfuric acid to achieve an acid concentration of $55 \%(\mathrm{w} / \mathrm{w})$ which was then vigorously stirred for $20 \mathrm{~min}$ at $60{ }^{\circ} \mathrm{C}$. Afterward, dialysis and ultrasonic treatment were followed as described for the preparation of woodbased whiskers. Reported tunicin whiskers have a width on the order of 10-20 nm, and a length ranges from $100 \mathrm{~nm}$ to several microns as summarized in Table 9.

\begin{tabular}{lllll}
\hline $\begin{array}{l}\text { Cellulosea, } \\
\text { wt } \%\end{array}$ & $\begin{array}{l}\text { Acida, } \\
\mathrm{wt} \%\end{array}$ & $\begin{array}{l}\text { Time, } \\
\min \end{array}$ & $\begin{array}{l}\mathrm{T}, \\
{ }^{\circ} \mathrm{C}\end{array}$ & Whiskers dimension \\
\hline 5 & 55 & 20 & 60 & $100 \mathrm{~nm}$-several $\mu \mathrm{m} \times 10-20 \mathrm{~nm}$ \\
5 & 55 & 20 & 60 & $500 \mathrm{~nm}-1-2 \mu \mathrm{m} \times 10 \mathrm{~nm}$ \\
- & 60 & 30 & 65 & $500 \mathrm{~nm}-1-2 \mu \mathrm{m} \times 15 \mathrm{~nm}$ \\
5 & 55 & 20 & 60 & $1-$ several $\mu \mathrm{m} \times 10-20 \mathrm{~nm}$ \\
- & 65 & Overnight & Room T & $1-2 \mu \mathrm{m} \times 8-15 \mathrm{~nm}$ \\
\hline
\end{tabular}

a Based on water content.

Table 9. Sulfuric acid hydrolysis conditions and dimensions of tunicate cellulose nano whiskers (Favier et al., 1995; Angles \& Dufresne, 2000; Samir et al., 2004; Ljungberg et al., 2006; Habibi et al., 2007). 
Enzymatic-mediated production of cellulose nano whiskers was studied by Filson et al. (2009). The highest yield of whiskers was obtained by treatment with 84 EGU of endoglucannase per $200 \mathrm{mg}$ recycled pulp at $50{ }^{\circ} \mathrm{C}$ for $60 \mathrm{~min}$ assisted by microwave or conventional heating. Microwave treatment was reported to give a higher yield than conventional heating. Enzymatically hydrolyzed whiskers were found to have a relatively larger size than acid hydrolyzed whiskers, typically 30 to $80 \mathrm{~nm}$ in width and $100 \mathrm{~nm}$ to 1.8 $\mu \mathrm{m}$ in length. In addition, a chemical swelling/ultrasonic separation method was also used to prepare wood-based cellulose nano whiskers (Oksman et al., 2006). MCC (10 wt\%) dissolved in a swelling solution of dimethylacetamide (DMAc) with $0.5 \mathrm{wt} \%$ of $\mathrm{LiCl}$ was treated at $70{ }^{\circ} \mathrm{C}$ for 12 hours with stirring. The slightly swollen particles were further separated in an ultrasonic bath for 3 hours over a period of 5 days with long intervals. The whiskers were estimated to be less than $10 \mathrm{~nm}$ in width and 200 to $400 \mathrm{~nm}$ in length.

\subsection{Characterization and properties of cellulose nano whiskers}

Transmission electron microscopy (TEM) is a powerful tool for the size measurement of cellulose nano whiskers. A sample is usually prepared by drying a drop of dilute whiskers suspension $(\sim 0.1 \% \mathrm{w} / \mathrm{v})$ on a carbon coated microscope grid (Dong et al., 1998). The particle dimension can be determined by manual counting from TEM micrographs at a high magnification, and the distributions of particle length and diameter are calculated by counting several individual particles in each sample. On some occasions, the sample can be stained with a uranyl acetate solution to enhance the resolution (de Rodriguez et al., 2006; Bai et al., 2009; Siqueira et al., 2010). Atomic force microscope (AFM) is another useful technique to characterize nano whiskers. In Bech-Candanedo et al.'s study (2005), a cellulose whiskers suspension was diluted to a concentration between $1 \times 10^{-3}$ and $1 \times 10^{-4} \mathrm{wt} \%$ and filtered through a $0.45 \mu \mathrm{m}$ membrane. A $20 \mu \mathrm{L}$ drop of $0.1 \% \mathrm{w} / \mathrm{v}$ poly-L-lysine solution was placed on a $1 \mathrm{~cm}^{2}$ piece of freshly cleaved mica for $3 \mathrm{~min}$, washed off with water and dried. A $10 \mu \mathrm{L}$ drop of whiskers was allowed to stand on the mica for $1 \mathrm{~min}$, rinsed off with water and dried. The mica was then attached to an AFM specimen disk and analyzed. In addition, particle size distribution, average molecular weight and zeta potential of cellulose nano whisker can also be determined by dynamic light scattering (Filson et al., 2009). As shown in the above tables, whiskers generally have a diameter of 3-20 nm and an aspect ratio of 20-60. Untreated cellulose fibers exhibited many steps of degradation according to the thermal gravimetric analysis (TGA) results, which included an initial moisture loss at $110{ }^{\circ} \mathrm{C}$, and intermediate loss at $280{ }^{\circ} \mathrm{C}$ and $352{ }^{\circ} \mathrm{C}$, while $\mathrm{H}_{2} \mathrm{SO}_{4}$-whiskers showed two well separated degradation processes, one started from 220 to $280{ }^{\circ} \mathrm{C}$ and the other was between 330 to 500 ${ }^{\circ} \mathrm{C}$, with initial moisture loss at $120{ }^{\circ} \mathrm{C}$ (Pandey et al., 2008). It was reported that the increase of the moisture loss temperature could be attributed to the strong adhesion of water molecules to the large surface of whiskers. It was also believed that the main degradation between $220{ }^{\circ} \mathrm{C}$ and $280{ }^{\circ} \mathrm{C}$ was due to depolymerization, dehydration, and decomposition of glycosyl units followed by the formation of a char, while the degradation above $325{ }^{\circ} \mathrm{C}$ could be ascribed to the oxidation and breakdown of the char to lower molecular weight gaseous products (Cao et al., 2009). It was argued that the lower degradation temperature of whiskers with sulfate groups was due to the increasing numbers of free end chains and sulfate groups at the surface, which were liable to earlier decomposition (Wang et al., 2007). A chiral nematic phase is a characteristic of a $\mathrm{H}_{2} \mathrm{SO}_{4}$-whiskers suspension (Dong et al., 1998; Revol et al., 1992), and phase separation is concentration-driven (Revol et al., 1994). The 
critical concentration for anisotropic phase formation can be measured by observing the amounts of isotropic and anisotropic phases in a series of samples with different concentrations (Dong et al., 1996; Dong et al., 1998). The anisotropic phase separates at relatively low concentration, e.g., $4 \mathrm{wt} \%$ for a salt-free whiskers suspension. The critical concentration for anisotropic phase formation was found to be slightly increased and the biphasic range became narrower, with longer hydrolysis time and/or higher acid to cellulose ratio which produced shorter, less polydispersed whiskers (Beck-Candanedo et al., 2005). It is not possible to observe any chiral nematic phase of whiskers hydrolyzed by other acids. Postsulfonated whiskers suspension showed a birefringent glassy phase different from the chiral nematic phase (Araki et al., 2000).

\section{Cellulose nano whisker/polyurethane nanocomposite}

\subsection{Starting materials}

Starting materials are highly important in view of the desired properties for specific applications of PUs. In general, at least two polyols and an isocyanate are required for a proper performance of PU. Difunctional polymers are preferred for a linear or low crosslinked PU as illustrated in Figure 2. In Marovich et al.'s work (2006), a mixture of di- and multi-functional polyols and polymeric 4,4'-diphenylmethane diisocyanate (MDI) were used. In Auad et al.'s study (2010), polyether glycol (PEG), MDI and 1,4-butanediol (BD) were chosen as raw materials. In case of waterborne PU (WPU), a diol such as polycaprolactone (PCL) and polypropylene glycol (PPG), an isocyanate such as isophorone diisocyanate (IPDI) and 2,4-toluene diisocyanate (TDI), an organic acid, typically dimethylol propionic acid (DMPA), and a catalyst like triethylamine (TEA) were used (Cao et al., 2007; Cao et al., 2009; Wang et al., 2010). In contrast, a highly cross-linked structure exists in rigid PU foam which calls for multifunctional polyols and isocyanates. Moreover, a foaming catalyst should be included in addition to the cross-linking catalyst, and a surfactant is often added to reduce surface tension and obtain a high content of closed cells. For example, sucrose-based and glycerol-based polyols with functionality of 4.4 and 3.0, respectively, polymeric MDI with functionality of 2.7, dimethylcyclohexylamine, 1-methyl-4-(2dimethylaminoethyl) piperazine, silicone surfactant and pentane were used by Li et al. (2010a).

$$
\begin{aligned}
& \mathrm{O}=\mathrm{C}=\mathrm{N}-\mathrm{R}^{1}-\mathrm{N}=\mathrm{C}=\mathrm{O}+\mathrm{HO}-\mathrm{R}^{2}-\mathrm{OH}+\mathrm{O}=\mathrm{C}=\mathrm{N}-\mathrm{R}^{1}-\mathrm{N}=\mathrm{C}=\mathrm{O}+\mathrm{HO}-\mathrm{R}^{2}-\mathrm{OH}+\cdots
\end{aligned}
$$

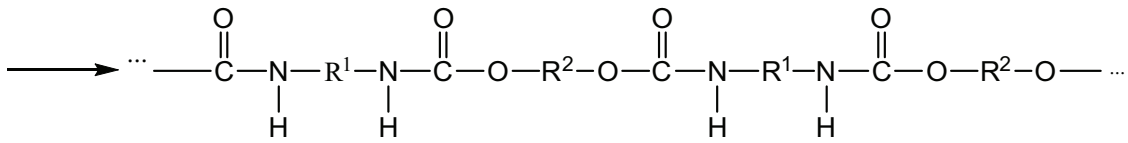

Fig. 2. Chemical reaction of linear polyurethanes synthesis.

\subsection{Preparation methods}

Due to strong hydrogen bonding interactions between cellulose hydroxyl groups, it is difficult to obtain well separated whiskers in organic solvents, especially for non-polar solvents. Since the dispersion of cellulose nano whiskers in organic solvents is crucial to surface chemical modification of whiskers and preparation of nanocomposites, several methods have been used to solve this issue. Dispersion of freeze-dried whiskers in a polar 
organic solvents such as dimethylformamide (DMF) or dimethylsulfoxide (DMSO) without surfactant or chemical modification of whiskers has been employed (Samir et al., 2004; Marcovich et al., 2006; Berg et al., 2007). A dilute whiskers suspension was prepared by vigorous mixing and intensive ultrasonic treatment of dried whiskers in organic solvents. In fact, microfibrillated cellulose dispersed in polar solvents such as glycerine, PEG and DMSO after freeze drying were also found to be feasible approaches (Viet et al., 2007). In addition, stable cellulose microfibrils suspensions in toluene and cyclohexane were obtained with the assistance of a phosphoric ester surfactant (Heux et al., 2000). Surface modification, such as partial silylation and grafting of low molecular weight PEG onto the surface of whiskers, is another way to suspend whiskers in non-polar organic solvents (Gousse et al., 2002).

In the past five years, cellulose nano whiskers have been widely used as reinforcing fillers in polyurethanes, including those prepared from MCC (Marcovich et al., 2006; Auad et al., 2008; Auad et al., 2010), flax fiber (Cao et al., 2007), cotton liner pulp (Cao et al., 2009; Wang et al., 2010) and bleached SW pulp (Li et al., 2010a) by acid hydrolysis proposed by Dong et al. (Dong et al., 1996). The dispersion of whiskers in DMF was accomplished either by ultrasonic treatment or a solvent exchange method (Cao et al., 2009).

To prepare a thermoplastic PU film, a whiskers suspension in DMF was first added to a polyol or polyols mixture with stirring which was then followed by ultrasonic treatment and solvent evaporation at $70{ }^{\circ} \mathrm{C}$. Afterward, isocyanate was added to reach a select isocyanate/hydroxyl ratio and mixed throughly. As isocyanate is a very reactive chemical and can easily react with a trace of water present in the starting materials and/or react with it self forming trimers, a molar ratio of isocyanate groups to hydroxyl groups higher than 1.0 is often used (Yao et al., 1995; Xu et al., 2007; Thirumal et al., 2008). The mixture was then cast into an open mold and cured under varying conditions (Marcovich et al., 2006; Auad et al., 2008; Auad et al., 2010). Whiskers content up to $5 \mathrm{wt} \%$ was examined in Marcovich's study and up to $1 \mathrm{wt} \%$ in Auad's work.

A detailed preparation of WPU can be found in Cao et al.'s study (2007 \& 2009). PCL and DMPA were introduced into a reaction flask equipped with a mechanical stirrer and a dropping funnel and heated to $80-85{ }^{\circ} \mathrm{C}$ until the PCL melted; IPDI was then added dropwise under a dry nitrogen atmosphere for several hours until the isocyanate content reached a desired value. Subsequently, a whiskers suspension in DMF was added, and the reaction lasted for several hours. Afterward, DMF was removed under reduced pressure at $60-80{ }^{\circ} \mathrm{C}$, and acetone was added to reduce the viscosity of the pre-polymer. Carboxylic groups of DMPA were then neutralized with TEA for $30 \mathrm{~min}$, and the product was dispersed in DI water with vigorous stirring at room temperature overnight. The solid content could be further increased to above $25 \mathrm{wt} \%$ by rotary vacuum evaporation at $30{ }^{\circ} \mathrm{C}$. The suspension was finally casted in teflon petri dishes and dried in an oven at $40-50{ }^{\circ} \mathrm{C}$ for 10-20 hours depending on water content. In Wang et al.'s study (2000), PPG instead of PCL, TDI instead of IPDI, and a whisker suspension in water instead of in DMF were used.

Rigid PU nanocomposite foam reinforced with cellulose nano whiskers has also been prepared (Li et al., 2010a). Whiskers in DMF were mixed with polyols under vigrous stirring followed by removal of DMF under reduced pressure. Catalysts and blowing agent were added and mixed when the mixture cooled down to room temperature. Polymeric MDI was then added and vigorously stirred for $\sim 20$ s until the self-rising started. Foams were left at room temperature for at least 48 hours before physical testing (Rivera-Armenta et al., 2004). 


\subsection{Characterizations and discussions}

The morphology and fracture surface of PU nanocomposites have been examined by scanning electron microscopy (SEM) (Marcovich et al., 2006; Cao et al., 2007; Auad et al., 2008; Cao et al., 2009; Auad et al., 2010; Li et al., 2010a) and TEM (Wang et al., 2010). The underlying chemical structure can be investigated by FT-IR (Cao et al., 2007; Li et al., 2010a), X-Ray photoelectron spectroscopy (Cao et al., 2009), and wide angle X-ray scattering (Cao et al., 2007; Auad et al., 2008; Cao et al., 2009). Thermomechanical response of specific samples can be determined by using a rheometer in the temperature scan mode while a deformation is applied (Auad et al., 2008), or by a dynamic mechanical analyzer (Marcovich et al., 2006; Cao et al., 2007; Auad et al., 2008; Cao et al., 2009; Auad et al., 2010; Li et al., 2010a; Wang et al., 2010). Differential scanning calorimetry (Marcovich et al., 2006; Cao et al., 2007; Auad et al., 2008; Cao et al., 2009; Auad et al., 2010) and thermal gravimetric analysis (Cao et al., 2009) are both useful tools to study the thermal of PUs stability. Tensile testing can be performed according to ASTM D 1708 (Marcovich et al., 2006; Cao et al., 2007; Auad et al., 2008; Cao et al., 2009; Auad et al., 2010) for PU films and ASTM D 638-08 for PU foams (Li et al., 2010a). ASTM C 365M-05 is a compression test standard for PU foams (Li et al., 2010a).

FT-IR spectra and SEM images of PU nanocomposite films indicated a well dispersion of cellulose nano whiskers in the matrix (Marcovich et al., 2006; Cao et al., 2007; Auad et al., 2008) and a good adhesion in the interfacial area attributed to strong hydrogen bonding (Cao et al., 2007). With respect to the rigid PU foams, it was shown that the closed cells had a homogeneous dispersion in the nanocomposites, and the cell sizes were around $350 \mu \mathrm{m}$ and decreased slightly with increasing whiskers content (Table 10) (Li et al., 2010b). This was presumably because whiskers served as nucleation sites to facilitate the bubble nucleation process, and the increased number of nucleation sites led to a finer cell structure (Alexandre \& Dubois, 2000; Lee et al., 2005). It was found that a higher energy was consumed in the cryofracture of nanocomposite films which could possibly improve the tearing characteristics (Marcovich et al., 2006). Tensile modulus of PU films was significantly improved at a small loading of whiskers, i.e., $0.5-5 \mathrm{wt} \%$, and this was more apparent at higher loadings such as 2.5 and $5.0 \mathrm{wt} \%$ of whiskers (Table 11) (Marcovich et al., 2006). Contrarily, the creep deformation decreased with increasing whiskers content. For example, incorporation of $1 \mathrm{wt} \%$ of whiskers resulted in a tensile modulus improvement of $\sim 53 \%$ and creep reduction of $\sim 36 \%$ (Auad et al., 2008). The changes are notable considering the relatively small amount of whiskers. With 10 wt $\%$ of whiskers, the Young's modulus and strength were significantly enhanced from 1.7 to 107.4 MPa and 4.4 to 9.7 MPa, respectively (Cao et al., 2009). A further increase of whiskers content to $30 \%$ resulted in an increase of Young's modulus and tensile strength from 0.5 to 344 $\mathrm{MPa}$ and 4.3 to $14.9 \mathrm{MPa}$, respectively (Cao et al., 2007). This can be ascribed, in part, to the three-dimension network of whiskers reinforced PU linked by intermolecular hydrogen bonding interactions. Additionally, cellulose nano whiskers become chemically bonded to the matrix during curing, through reaction of hydroxyl groups with isocyanate groups which leads to an increase of the glass transition temperature $\left(T_{\mathrm{g}}\right)$ and has a positive effect on tensile property of PU (Li et al., 2010b). It was also found that a phase separation of soft and hard domains was favored by whiskers addition which led to an upward shift in melting temperature $\left(T_{m}\right)$ of crystalline phase, an increase in Young's modulus, and a decrease in deformation at break (Auad et al., 2008 \& 2010). A remarkable synergistic effect of starch nano crystals (SN) and cellulose nano whiskers (CW) on reinforcing WPU has been observed. Upon incorporation of $1 \mathrm{wt} \% \mathrm{SN}$ and $0.4 \mathrm{wt} \% \mathrm{CW}$, tensile strength, Young's modulus and tensile energy at break of the nanocomposite were significantly improved by $135 \%, 252 \%$ and $136 \%$, 
respectively, and the elongation at break remained comparable to the pure WPU (Wang et al., 2010). In Cao et al.'s study (2009), it was demonstrated that WPU chains formed crystalline domains on the surface of whiskers which expedited the crystallization of PCL in nanocomposites. This co-crystallization phenomenon is believed to induce the formation of a co-continuous phase between the filler and matrix which significantly enhanced the interfacial adhesion and consequently contributed to an improvement in thermal stability and mechanical strength of the nanocomposites. PU foam reinforced with $0.75 \mathrm{wt} \%$ and $1.00 \mathrm{wt} \%$ of cellulose nano whiskers showed improved tensile and compressive properties as well as enhanced thermal stability indicated by $T_{g}$ and $T_{d}$ (decomposition temperature) (Li et al., $2010 \mathrm{~b}$ ). A detailed comparison of mechanical and thermal properties between the neat PU and PU nanocomposites mentioned above is summarized in Table 11.

\begin{tabular}{l|lllll}
\hline Whiskers content, wt $\%$ & 0 & 0.25 & 0.5 & 0.75 & 1.00 \\
\hline Cell size, $\mu \mathrm{m}$ & $376 \pm 41$ & $358 \pm 25$ & $345 \pm 54$ & $339 \pm 28$ & $323 \pm 23$ \\
\hline
\end{tabular}

Table 10. Cell size of rigid PU nanocomposite foams (Li et al., 2010b).

\section{Cellulose fiber and microfibril reinforced polyurethane}

Mechanical properties of PU elastomers reinforced with bacterial cellulose microfibers of different aspect ratios were investigated by Bicerano \& Brewbaker (1995). It was found that microfibers with a relatively high aspect ratio nearly doubled the Young's modulus and tripled the strength which far surpassed those observed for microfibers of modest aspect ratios. Although cellulose nano whiskers were not discussed, it proved that a high aspect ratio, one of the characteristics of whiskers, had a considerable positive effect on the improvement of mechanical properties. Green algae cellulose fibers of 500 to $600 \mu \mathrm{m}$ in length and 20 to $200 \mu \mathrm{m}$ in width were used to prepare a PU composite foam by Johnson \& Shivkumar (2004). It was reported that the peak mechanical of properties the composite foams were obtained at a dry fiber content of 5-10 wt $\%$, while a maximum of $40 \mathrm{wt} \%$ incorporation, based on the total weight of isocyanate and polyol, were investigated. There was no data on the mechanical improvements of PU composites compared to the neat foam. However, the tensile modulus of the dried algae fibers was measured to be on the order 20$45 \mathrm{MPa}$, while cellulose nano whiskers have a much higher value of $143 \mathrm{GPa}$, which makes whiskers a possible stonger reinforcing filler compared to algae fibers. Vegetal cellulose fibers were also used in preparation of PU composites (Silva \& Silva, 2005). Hydrogen bonding interactions and covalent linkages between cellulose fibers and polymeric matrix were found by FT-IR but the mechanical properties of nanocomposites were not discussed. Later on, Wu et al. (2007) did a comparison study on cellulose fiber versus nanofibril reinforced high strength elastomeric PU nanocomposites. Cellulose fibers used in the reported study were 1-2 $\mathrm{mm}$ in length, while the nanofibrils, prepared by dissolution of MCC ( $50 \mu \mathrm{m}$ average particle size) in DMF containing trace amount of $\mathrm{LiCl}(<0.3 \mathrm{wt} \%)$, were 20 to $40 \mathrm{~nm}$ in diameter and 450-900 nm in length. Date shown in Table 13 indicated that cellulose nanofibrils had a significant reinforcing effect on the tensile properties of elastomeric PU, while cellulose fibers gave a mild increase of tensile modulus but a decrease of tensile strength and the strain-to-failure. It was stated that the size scale of MCC was typically in the order of tens of microns and above, and it was likely that the less successful reinforcement effect was due to micro- rather than nanoscale dispersion of the fillers (Wu et 
al, 2007). In Mosievicki et al.'s study (2009), MCC was found to be poorly dispersed into the PU matrix because of the agglomeration of crystalline particles which resulted in lower mechanical and dynamic mechanical properties; however, the thermal stability was enhanced at high temperatures. Generally, the intrinsic high strength, high aspect ratio of cellulose nano whiskers, as well as the nanoscale effect makes it a superior reinforcing filler in comparison with cellulose fibers or microfibrils.

\begin{tabular}{|c|c|c|c|c|c|c|c|c|c|}
\hline \multirow{2}{*}{$\begin{array}{c}\text { Thermoplastic } \\
\text { PUs }\end{array}$} & \multirow{2}{*}{$\begin{array}{c}\text { Whiskers } \\
\text { dimesion, } \\
\mathrm{nm}^{2}\end{array}$} & \multirow{2}{*}{$\begin{array}{c}\text { Whiskers } \\
\text { content, } \\
\text { wt } \%\end{array}$} & \multirow{2}{*}{$\begin{array}{c}\text { Young's } \\
\text { modulus } \\
\text { change, } \%\end{array}$} & \multirow{2}{*}{$\begin{array}{c}\text { Tensile } \\
\text { strength } \\
\text { change, \% }\end{array}$} & \multirow{2}{*}{$\begin{array}{c}\text { Elongation } \\
\text { at break } \\
\text { change, \% }\end{array}$} & \multicolumn{2}{|c|}{$\begin{array}{cc}T_{g} & T_{d} \\
\text { change, change, }\end{array}$} & \multicolumn{2}{|c|}{$\begin{array}{c}T_{m} \text { change, } \\
\%\end{array}$} \\
\hline & & & & & & & & Sc & $\mathrm{H}^{\mathrm{d}}$ \\
\hline \multirow{4}{*}{$\begin{array}{l}\text { Polyol } \\
\text { mixture + } \\
\text { polymeric } \\
\text { MDI }\end{array}$} & $100-225 \times$ & 0.5 & +55.1 & $-18.48^{a}$ & -43.6 & - & - & - & - \\
\hline & $10-15$ & 1.0 & +50.6 & $-48.5^{a}$ & -54.5 & - & - & - & - \\
\hline & & 2.5 & +102.8 & $-29.0^{a}$ & -50.9 & $+53.5^{b}$ & - & - & - \\
\hline & & 5.0 & +143.6 & $-37.8^{a}$ & -52.7 & - & - & - & - \\
\hline \multirow{3}{*}{$\begin{array}{l}\text { Commercial } \\
\text { polyester PU }\end{array}$} & Hundreds & 0.1 & - & - & - & +0.55 & - & +0.73 & +2.27 \\
\hline & $\times 10-20$ & 0.5 & - & - & - & +1.37 & - & +2.93 & +4.25 \\
\hline & & 1.0 & - & - & - & +2.19 & - & +5.12 & +2.05 \\
\hline PEG $650+$ MDI & $2500-5000$ & 0.1 & - & - & - & - & - & - & - \\
\hline \multirow{2}{*}{$(48 w t \%)$} & $\times 50-100$ & 0.5 & -2.29 & - & +11.3 & - & - & - & - \\
\hline & & 1.0 & -1.16 & - & -14.2 & - & - & - & - \\
\hline PEG 2000 + & & 0.1 & - & - & - & - & - & +18.3 & \\
\hline \multirow[t]{2}{*}{ MDI (45 wt \%) } & & 0.5 & -29.4 & - & -92.1 & - & - & +60.0 & \\
\hline & & 1.0 & -21.6 & - & -81.8 & - & - & +35.0 & \\
\hline PEG 2000 + & & 0.1 & - & - & - & - & - & +9.6 & 0 \\
\hline \multirow[t]{2}{*}{ MDI (40wt $\%)$} & & 0.5 & +37.9 & - & -83.3 & & - & +57.7 & \\
\hline & & 1.0 & +34.0 & - & -75.9 & - & - & +55.8 & \\
\hline PEG 2000 + & & 0.1 & - & - & - & - & - & +38.2 & \\
\hline \multirow[t]{2}{*}{ MDI (32 wt $\%)$} & & 0.5 & +49.1 & - & -82.9 & - & - & +70.6 & \\
\hline & & 1.0 & +53.6 & - & -89.9 & - & - & +32.4 & \\
\hline PEG $2000+$ & & 0.1 & - & - & - & - & - & +73.3 & \\
\hline \multirow{2}{*}{ MDI (23 wt $\%)$} & & 0.5 & +42.5 & - & -87.9 & - & - & +50.7 & \\
\hline & & 1.0 & +44.5 & - & -93.4 & - & - & +56.0 & \\
\hline \multirow[t]{12}{*}{ Waterborne PU } & $70-150 \times$ & 2 & +218 & +43.2 & +21.3 & +6.65 & $\sim 15.8$ & 42.51 & ${ }^{\circ} \mathrm{C}$ \\
\hline & $10-20$ & 4 & +1224 & +70.5 & +29.1 & +5.67 & & 41.76 & ${ }^{\circ} \mathrm{C}$ \\
\hline & & 6 & +2335 & +102 & -2.1 & +7.07 & & 42.56 & ${ }^{\circ} \mathrm{C}$ \\
\hline & & 8 & +3171 & +114 & -21.2 & +5.63 & & 41.66 & ${ }^{\circ} \mathrm{C}$ \\
\hline & & 10 & +6218 & +120 & -40.3 & +9.38 & & 42.63 & ${ }^{\circ} \mathrm{C}$ \\
\hline & $327 \pm 108 \times$ & 5 & +40.0 & +116 & -9.19 & -1.75 & - & - & - \\
\hline & $21 \pm 7$ & 10 & +1460 & +137 & -32.3 & -2.92 & - & - & - \\
\hline & & 15 & +940 & +181 & -43.4 & -3.31 & - & - & - \\
\hline & & 20 & +23220 & +186 & -61.3 & -4.67 & - & - & - \\
\hline & & 25 & +47280 & +230 & -68.6 & -4.47 & - & - & - \\
\hline & & 30 & +66780 & +247 & -82.9 & -5.25 & - & - & - \\
\hline & $0 \times 80-100$ & 0.4 & +140 & +66.7 & -4.11 & $-7.00^{\mathrm{b}}$ & $+11.1^{\mathrm{e}}$ & - & - \\
\hline
\end{tabular}

${ }^{a}$ yield strength change, $\%$; ${ }^{b}$ based on $T_{a}$ (glass-rubber relaxation temperature); ${ }^{\mathrm{c}}$ softsegments; ${ }^{\mathrm{d}}$

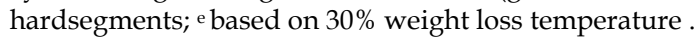

Table 11. Improvement of mechanical and thermal properties of PU/cellulose nano whisker composite elastomers (Marcovich et al., 2006; Cao et al., 2007; Auad et al., 2008; Cao et al., 2009; Auad et al., 2010; Wang et al., 2010). 


\begin{tabular}{llllllll}
\hline $\begin{array}{l}\text { Whiskers } \\
\text { content, } \\
\text { wt } \%\end{array}$ & $\begin{array}{l}\text { Tensile } \\
\text { modulus } \\
\text { change, } \%\end{array}$ & $\begin{array}{l}\text { Yield } \\
\text { strength } \\
\text { change, } \%\end{array}$ & $\begin{array}{l}\text { Tensile } \\
\text { strength } \\
\text { change, } \%\end{array}$ & $\begin{array}{l}\text { Compressive } \\
\text { strength } \\
\text { change, } \%\end{array}$ & $\begin{array}{l}\text { Compressive } \\
\text { modulus } \\
\text { change, } \%\end{array}$ & $\begin{array}{l}T_{g} \\
\text { change, } \\
\%\end{array}$ & $\begin{array}{l}T_{d} \\
\text { change, }\end{array}$ \\
\hline 0.25 & -30.4 & -34.2 & -27.0 & +29.0 & +66.6 & +6.8 & -1.2 \\
0.50 & -20.6 & -22.8 & -21.4 & +131.0 & +118.5 & +13.6 & -0.6 \\
0.75 & +36.8 & +15.2 & +13.8 & +143.4 & +179.9 & +10.2 & +0.9 \\
1.00 & +227.2 & +112.0 & +99.2 & +269.7 & +210.0 & +10.2 & +3.0 \\
\hline
\end{tabular}

Table 12. Improvement of mechanical and thermal properties of PU/cellulose nano whisker composite foams (Li et al., 2010b).

\begin{tabular}{llll}
\hline $\begin{array}{l}\text { PU reinforced with } \\
\text { filler }\end{array}$ & $\begin{array}{l}\text { Tensile modulus } \\
\text { change, } \%\end{array}$ & $\begin{array}{l}\text { Tensile strength } \\
\text { change, \% }\end{array}$ & $\begin{array}{l}\text { Strain-to-failuor } \\
\text { change, } \%\end{array}$ \\
\hline Fiber, 5 wt\% & +28.6 & -20.5 & -62.7 \\
Nanofibril, 5 wt\% & +163.3 & +110.3 & +169.8 \\
\hline
\end{tabular}

Table 13. A comparison between cellulose fibers and nanofibrils reinforced PUs in terms of tensile properties (Wu et al., 2007).

\section{Summary and conclusions}

The wide availability, renewable and biodegradable features, simple hydrolysis process, and high intrinsic strength and modulus, high aspect ratio and reactivity make cellulose nano whiskers superior to other traditional nano fillers. The reinforcing effect of whiskers in PU is accomplished through both chemical and hydrogen bonding between whiskers and/or the and matrix. Improvements of thermal and mechanical properties of cellulose nano whiskers reinforced nanocomposites are remarkable compared to some other inorganic fillers as well as cellulose fibers and microfibrils. The dispersion difficulty due to hydrophilicity of whiskers has been overcome by either physical or chemical methods. Techniques to produce low polydispersity cellulose nano whiskers are being developed, and it will facilitate improved property control and broaden the applications of cellulose nano whiskers in the future. Incorporation of cellulose nano whiskers in polyurethane and many other polymers has shown huge potential in industrial and consumer uses. Tremendous ongoing work makes it a promising next generation of nano fillers.

\section{Acknowledgement}

The authors would like to acknowledge the financial support from the PSE Fellowship program at IPST@GT. This work is part of the first author's requirements for the degree of Ph.D. at Georgia Institute of Technology.

\section{References}

Alexandre M. \& Dubois P. (2000) Polymer-layered silicate nanocomposites: preparation, properties and uses of a new class of materials. Materials science and engineering. $R$, $28,1,1-63$

Angles, M. N. \& Dufresne, A. (2000). Plasticized starch/tunicin whiskers nanocomposites. 1. Structural analysis. Macromolecules, 33, 22, 8344-8353 
Araki, J.; Wada, M.; Kuga, S. \& Okano, T. (1998). Flow properties of microcrystalline cellulose suspension prepared by acid treatment of native cellulose. Colloids and Surfaces a-Physicochemical and Engineering Aspects, 142, 1, 75-82

Araki, J.; Wada, M.; Kuga, S. \& Okana, T. (1999). Influence of surface charge on viscosity behavior of cellulose microcrystal suspension. Journal of Wood Science, 45, 3, 258-261

Araki, J.; Wada, M.; Kuga, S. \& Okano, T. (2000). Birefringent glassy phase of a cellulose microcrystal suspension. Langmuir, 16, 6, 2413-2415

Auad, M. L.; Contos, V. S.; Nutt, S.; Aranguren, M. I. \& Marcovich, N. E. (2008). Characterization of nanocellulose-reinforced shape memory polyurethanes. Polymer International, 57, 4, 651-659

Auad, M. L.; Mosiewicki, M. A.; Richardson, T.; Aranguren, M. I. \& Marcovich, N. E. (2010). Nanocomposites Made from Cellulose Nanocrystals and Tailored Segmented Polyurethanes. Journal of Applied Polymer Science, 115, 2, 1215-1225

Bai, W.; Holbery, J. \& Li, K. C. (2009). A technique for production of nanocrystalline cellulose with a narrow size distribution. Cellulose, 16, 3, 455-465

Beck-Candanedo, S.; Roman, M. \& Gray, D. G. (2005). Effect of reaction conditions on the properties and behavior of wood cellulose nanocrystal suspensions. Biomacromolecules, 6, 2, 1048-1054

Berg, O.; Capadona, J. R. \& Weder, C. (2007). Preparation of Homogeneous dispersions of tunicate cellulose whiskers in organic solvents. Biomacromolecules, 8, 4, 1353-1357

Bicerano, J. \& Brewbaker, J. L. (1995). Reinforcement of polyurethane elastomers with microfibers having varing aspect ratios. Journal of the Chemical Society-Faraday Transactions, 91, 16, 2507-2513

Bondeson, D.; Mathew, A. \& Oksman, K. (2006). Optimization of the isolation of nanocrystals from microcrystalline cellulose by acid hydrolysis. Cellulose, 13, 2, 171180

Bondeson, D. \& Oksman, K. (2007). Polylactic acid/cellulose whisker nanocomposites modified by polyvinyl alcohol. Composites Part a-Applied Science and Manufacturing, $38,12,2486-2492$

Cao, X. D.; Dong, H. \& Li, C. M. (2007). New nanocomposite materials reinforced with flax cellulose nanocrystals in waterborne polyurethane. Biomacromolecules, 8, 3, 899-904

Cao, X. D.; Habibi, Y. \& Lucia, L. A. (2009). One-pot polymerization, surface grafting, and processing of waterborne polyurethane-cellulose nanocrystal nanocomposites. Journal of Materials Chemistry, 19, 38, 7137-7145

de Rodriguez, N. L. G.; Thielemans, W. \& Dufresne, A. (2006). Sisal cellulose whiskers reinforced polyvinyl acetate nanocomposites. Cellulose, 13, 3, 261-270

Dong, X. M.; Kimura, T.; Revol, J. F. \& Gray, D. G. (1996). Effects of ionic strength on the isotropic-chiral nematic phase transition of suspensions of cellulose crystallites. Langmuir, 12, 8, 2076-2082

Dong, X. M.; Revol, J. F. \& Gray, D. G. (1998). Effect of microcrystallite preparation conditions on the formation of colloid crystals of cellulose. Cellulose, 5, 1, 19-32

Dufresne, A.; Kellerhals, M. B. \& Witholt, B. (1999). Transcrystallization in MclPHAs/cellulose whiskers composites. Macromolecules, 32, 22, 7396-7401

Eichhorn, S. J.; Baillie, C. A.; Zafeiropoulos, N.; Mwaikambo, L. Y.; Ansell, M. P.; Dufresne, A.; et al. (2001). Review: Current international research into cellulosic fibres and composites. Journal of Materials Science, 36, 9, 2107-2131 
Favier, V.; Chanzy, H. \& Cavaille, J. Y. (1995). Polymer nanocomposites reinforced by cellulose whiskers. Macromolecules, 28, 18, 6365-6367

Filson, P. B.; Dawson-Andoh, B. E. \& Schwegler-Berry, D. (2009). Enzymatic-mediated production of cellulose nanocrystals from recycled pulp. Green Chemistry, 11, 11, $1808-1814$

Gousse, C.; Chanzy, H.; Excoffier, G.; Soubeyrand, L. \& Fleury, E. (2002). Stable suspensions of partially silylated cellulose whiskers dispersed in organic solvents. Polymer, 43, 9, 2645-2651

Grunert, M. \& Winter, W. T. (2002). Nanocomposites of cellulose acetate butyrate reinforced with cellulose nanocrystals. Journal of Polymers and the Environment, 10, 1-2, 27-30

Habibi, Y. \& Dufresne, A. (2008). Highly filled bionanocomposites from functionalized polysaccharide nanocrystals. Biomacromolecules, 9, 7, 1974-1980

Habibi, Y.; Foulon, L.; Aguie-Beghin, V.; Molinari, M. \& Douillard, R. (2007). LangmuirBlodgett films of cellulose nanocrystals: Preparation and characterization. Journal of Colloid and Interface Science, 316, 2, 388-397

Hanley, S. J.; Giasson, J.; Revol, J. F. \& Gray, D. G. (1992). Atomic force microscopy of cellulose microfibrils - comparison with transmission electron-microscopy. Polymer, 33, 21, 4639-4642

Hasani, M.; Cranston, E. D.; Westman, G. \& Gray, D. G. (2008). Cationic surface functionalization of cellulose nanocrystals. Soft Matter, 4, 11, 2238-2244

Helbert, W.; Cavaille, J. Y. \& Dufresne, A. (1996). Thermoplastic nanocomposites filled with wheat straw cellulose whiskers .1. Processing and mechanical behavior. Polymer Composites, 17, 4, 604-611

Heux, L.; Chauve, G. \& Bonini, C. (2000). Nonflocculating and chiral-nematic self-ordering of cellulose microcrystals suspensions in nonpolar solvents. Langmuir, 16, 21, 82108212

Ioelovich, M. Y. (1993). A study on formation of supermolecular structure of cotton cellulose. Vysokomolekulyarnye Soedineniya Seriya a \& Seriya B, 35, 5, B268-B271

Ioelovich, M. \& Larina, E. (1999). Parameters of crystalline structure and their influence on the reactivity of cellulose I. Cellulose Chemistry and Technology, 33, 1-2, 3-12

Ioelovich, M. (2009). Accessibility and crystallinity of cellulose. Bioresources, 4, 3, 1168-1177

Ioelovich, M. \& Leykin, A. (2009). Accessibility and supermolecular structure of cellulose. Cellulose Chemistry and Technology, 43, 9-10, 379-385

Johnson, M. \& Shivkumar, S. (2004). Filamentous green algae additions to isocyanate based foams. Journal of Applied Polymer Science, 93, 5, 2469-2477

Kamel, S. (2007). Nanotechnology and its applications in lignocellulosic composites, a mini review. Express Polymer Letters, 1, 9, 546-575

Klemm, D.; Heublein, B.; Fink, H. P. \& Bohn, A. (2005). Cellulose: Fascinating biopolymer and sustainable raw material. Angewandte Chemie-International Edition, 44, 22, 33583393

Lee L. J.; Zeng C.; Cao X.; Han X.; Shen J. \& Xu G. (2005) Polymer nanocomposite foams. Composites science and technology, 65, 15-16, 2344-2363

Li, Y.; Ren, H. F. \& Ragauskas, A. J. (2010a) . Rigid polyurethane foam reinforced with cellulose whiskers: Synthesis and characterization. [journal article]. Nano-Micro Letters, 2, 2, 6 
Li, Y.; Ren, H. F. \& Ragauskas, A. J. (2010b). Rigid polyurethane foam/cellulose whisker nanocomposites: preparation, characterization, and properties. Accepted by Journal of nanoscience and nanotechnology

Lim, H.; Kim, S. H. \& Kim, B. K. (2008). Effects of silicon surfactant in rigid polyurethane foams. Express Polymer Letters, 2, 3, 194-200

Liu, D. G.; Zhong, T. H.; Chang, P. R.; Li, K. F. \& Wu, Q. L. (2010). Starch composites reinforced by bamboo cellulosic crystals. Bioresource Technology, 101, 7, 2529-2536

Liu, H. Y.; Liu, D. G.; Yao, F. \& Wu, Q. L. (2010). Fabrication and properties of transparent polymethylmethacrylate/cellulose nanocrystals composites. Bioresource Technology, $101,14,5685-5692$

Ljungberg, N.; Cavaille, J. Y. \& Heux, L. (2006). Nanocomposites of isotactic polypropylene reinforced with rod-like cellulose whiskers. Polymer, 47, 18, 6285-6292

Marcovich, N. E.; Auad, M. L.; Bellesi, N. E.; Nutt, S. R. \& Aranguren, M. I. (2006). Cellulose micro/nanocrystals reinforced polyurethane. Journal of Materials Research, 21, 4, 870881

Mathew, A. P. \& Dufresne, A. (2002). Morphological investigation of nanocomposites from sorbitol plasticized starch and tunicin whiskers. Biomacromolecules, 3, 3, 609-617

Mohanty, A. K., Misra M. \& Drzal, L. T. (2005). Natural fibers, biopolymers, and biocomposites, CRC Press, 978-0-8493-1741-5, Florida

Morin, A. \& Dufresne, A. (2002). Nanocomposites of chitin whiskers from Riftia tubes and poly(caprolactone). Macromolecules, 35, 6, 2190-2199

Mosiewicki, M. A.; Casado, U.; Marcovich, N. E. \& Aranguren, M. I. (2009). Polyurethanes From Tung Oil: Polymer Characterization and Composites. Polymer Engineering and Science, 49, 4, 685-692

Oksman, K.; Mathew, A. P.; Bondeson, D. \& Kvien, I. (2006). Manufacturing process of cellulose whiskers/polylactic acid nanocomposites. Composites Science and Technology, 66, 15, 2776-2784

Pandey, J. K.; Lee, J. W.; Chu, W. S.; Kim, C. S. \& Ahn, S. H. (2008). Cellulose nano whiskers from grass of Korea. Macromolecular Research, 16, 5, 396-398

Pandey, J. K.; Kim, C. S.; Chu, W. S.; Lee, C. S.; Jang, D. Y. \& Ahn, S. H. (2009). Evaluation of morphological architecture of cellulose chains in grass during conversion from macro to nano dimensions. E-Polymers, no. 2

Pascault J., Sautereau H., Verdu J. \& Williams R. J. J. (2002). Thermosetting polymers, Marcel Dekker, 0-8247-0670-6, USA

Pei, A. H.; Zhou, Q. \& Berglund, L. A. (2010). Functionalized cellulose nanocrystals as biobased nucleation agents in poly(L-lactide) (PLLA) - Crystallization and mechanical property effects. Composites Science and Technology, 70, 5, 815-821

Pu, Y. Q.; Zhang, J. G.; Elder, T.; Deng, Y. L.; Gatenholm, P. \& Ragauskas, A. J. (2007). Investigation into nanocellulosics versus acacia reinforced acrylic films. Composites Part B-Engineering, 38, 3, 360-366.

Revol, J. F.; Bradford, H.; Giasson, J.; Marchessault, R. H. \& Gray, D. G. (1992). Helicoidal self-ordering of cellulose microfibrils in aqueous suspension. International Journal of Biological Macromolecules, 14, 3, 170-172

Revol, J. F.; Godbout, L.; Dong, X. M.; Gray, D. G.; Chanzy, H. \& Maret, G. (1994). Chiral nematic suspensions of cellulose crystallites - Phase separation and magnetic field orientation. Liquid Crystals, 16, 1, 127-134 
Rivera-Armenta, J. L.; Heinze, T. \& Mendoza-Martinez, A. M. (2004). New polyurethane foams modified with cellulose derivatives. European Polymer Journal, 40, 12, 2803 2812

Roman, M. \& Winter, W. T. (2004). Effect of sulfate groups from sulfuric acid hydrolysis on the thermal degradation behavior of bacterial cellulose. Biomacromolecules, 5, 5, 1671-1677

Samir, M.; Alloin, F.; Sanchez, J. Y.; El Kissi, N. \& Dufresne, A. (2004). Preparation of cellulose whiskers reinforced nanocomposites from an organic medium suspension. Macromolecules, 37, 4, 1386-1393

Samir, M.; Alloin, F.; Sanchez, J. Y. \& Dufresne, A. (2004). Cross-linked nanocomposite polymer electrolytes reinforced with cellulose whiskers. Macromolecules, 37, 13, 4839-4844

Samir, M.; Alloin, F. \& Dufresne, A. (2005). Review of recent research into cellulosic whiskers, their properties and their application in nanocomposite field. Biomacromolecules, 6, 2, 612-626

Selim, I. Z.; Zikry, A. A. F. \& Gaber S. H. (2004) Physicochemical properties of prepared cellulose sulfates: II. From linen pulp bleached by the $\mathrm{H}_{2} \mathrm{O}_{2}$ method. Polymer-plastics technology and engineering, 43, 5, 1387-1402

Silva, M. C.,\& Silva, G. G. (2005). A new composite from cellulose industrial waste and elastomeric polyurethane. Journal of Applied Polymer Science, 98, 1, 336-340

Siqueira, G.; Bras, J. \& Dufresne, A. (2010). New Process of Chemical Grafting of Cellulose Nanoparticles with a Long Chain Isocyanate. Langmuir, 26, 1, 402-411

Sturcova, A.; Davies, G. R. \& Eichhorn, S. J. (2005). Elastic modulus and stress-transfer properties of tunicate cellulose whiskers. Biomacromolecules, 6, 2, 1055-1061

Tang, L. M. \& Weder, C. (2010). Cellulose Whisker/Epoxy Resin Nanocomposites. Acs Applied Materials \& Interfaces, 2, 4, 1073-1080

Terech, P.; Chazeau, L. \& Cavaille, J. Y. (1999). A small-angle scattering study of cellulose whiskers in aqueous suspensions. Macromolecules, 32, 6, 1872-1875

Thirumal, M.; Khastgir, D.; K.Singha, N.; Manjunath, B. S. \& Naik, Y. P. (2008). Effect of foam density on the properties of water blown rigid polyurethane foam. Journal of applied polymer science, 108, 3, 1810-1817

Vajay, V. K. (2009). Biogas enrichment and bottling technology for vehicular use developed at ITT Delhi. FITT Forum, 15, 1, 2-3

Vermette, P.; Griesser, H. J.; Laroche, G. \& Guidoin R. (2001). Biomedical applications of polyurethanes, Eurekah.com, 1-58706-023-X, Texas

Viet, D.; Beck-Candanedo, S. \& Gray, D. G. (2007). Dispersion of cellulose nanocrystals in polar organic solvents. Cellulose, 14, 2, 109-113

Wang, N.; Ding, E.; \& Cheng R. (2007). Thermal degradation behaviors of spherical cellulose nanocrystals with sulfate groups. Polymer, 48, 12, 3486-3493

Wang, Y. X.; Tian, H. F. \& Zhang, L. N. (2010). Role of starch nanocrystals and cellulose whiskers in synergistic reinforcement of waterborne polyurethane. Carbohydrate Polymers, 80, 3, 665-671

Wise, L.E.; Murphy, M.; D'Adieco, A.A. (1946). Chlorite holocellulose, its fractionation and bearing on summative wood analysis and on studies on the hemicelluloses, Paper Trade J, 122, 2, 35-43 
Wu, Q. J.; Henriksson, M.; Liu, X. \& Berglund, L. A. (2007). A high strength nanocomposite based on microcrystalline cellulose and polyurethane. Biomacromolecules, 8, 12, 3687-3692

Xu, Z. B.; Tang, X. L.; Gu, A. J. \& Fang, Z. P. (2007). Novel preparation and mechanical properties of rigid polyurethane foam/organoclay nanocomposites. Journal of applied polymer science, 106, 1, 439-447

Yao Y.; Yoshioka, M. \& Shiraishi, N. (1995). Rigid polyurethane foams from combined liquefaction mixtures of wood and starch. Mokuzai Gakkaishi, 41, 7, 659-668

Zoppe, J. O.; Peresin, M. S.; Habibi, Y.; Venditti, R. A. \& Rojas, O. J. (2009). Reinforcing Poly(epsilon-caprolactone) Nanofibers with Cellulose Nanocrystals. Acs Applied Materials \& Interfaces, 1, 9, 1996-2004 


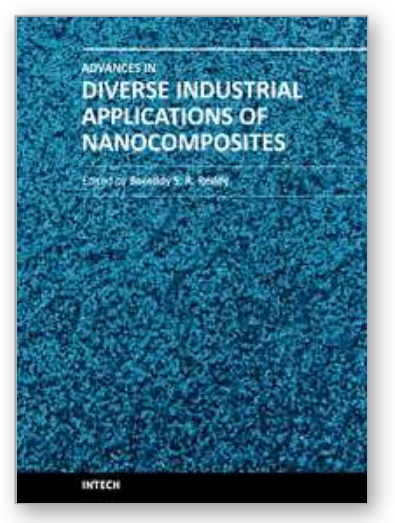

\author{
Advances in Diverse Industrial Applications of Nanocomposites \\ Edited by Dr. Boreddy Reddy
}

ISBN 978-953-307-202-9

Hard cover, 550 pages

Publisher InTech

Published online 22, March, 2011

Published in print edition March, 2011

Nanocomposites are attractive to researchers both from practical and theoretical point of view because of combination of special properties. Many efforts have been made in the last two decades using novel nanotechnology and nanoscience knowledge in order to get nanomaterials with determined functionality. This book focuses on polymer nanocomposites and their possible divergent applications. There has been enormous interest in the commercialization of nanocomposites for a variety of applications, and a number of these applications can already be found in industry. This book comprehensively deals with the divergent applications of nanocomposites comprising of 22 chapters.

\title{
How to reference
}

In order to correctly reference this scholarly work, feel free to copy and paste the following:

Yang Li and Arthur J. Ragauskas (2011). Cellulose Nano Whiskers as a Reinforcing Filler in Polyurethanes, Advances in Diverse Industrial Applications of Nanocomposites, Dr. Boreddy Reddy (Ed.), ISBN: 978-953-307202-9, InTech, Available from: http://www.intechopen.com/books/advances-in-diverse-industrial-applicationsof-nanocomposites/cellulose-nano-whiskers-as-a-reinforcing-filler-in-polyurethanes

\section{INTECH}

open science | open minds

\section{InTech Europe}

University Campus STeP Ri

Slavka Krautzeka 83/A

51000 Rijeka, Croatia

Phone: +385 (51) 770447

Fax: +385 (51) 686166

www.intechopen.com

\section{InTech China}

Unit 405, Office Block, Hotel Equatorial Shanghai

No.65, Yan An Road (West), Shanghai, 200040, China

中国上海市延安西路65号上海国际贵都大饭店办公楼405单元

Phone: +86-21-62489820

Fax: +86-21-62489821 
(C) 2011 The Author(s). Licensee IntechOpen. This chapter is distributed under the terms of the Creative Commons Attribution-NonCommercialShareAlike-3.0 License, which permits use, distribution and reproduction for non-commercial purposes, provided the original is properly cited and derivative works building on this content are distributed under the same license. 